\title{
Antibacterial effects of silver-zirconia composite coatings using pulsed laser deposition onto 316 L SS for bio implants
}

\author{
G. Pradhaban • Gobi Saravanan Kaliaraj • \\ Vinita Vishwakarma
}

Received: 27 May 2014/ Accepted: 11 September 2014/Published online: 14 November 2014

(C) The Author(s) 2014. This article is published with open access at Springerlink.com

\begin{abstract}
Bacterial invasion on biomedical implants is a challenging task for long-term and permanent implant fixations. Prevention of initial bacterial adherence on metallic implants is an important concern to avoid extracellular matrix (biofilm) secretion from bacteria that is resistant to antibacterial agents. In order to overcome this defect, recently, surface coatings such as zirconia $\left(\mathrm{ZrO}_{2}\right)$ with higher smoothness have been shown to improve implants durability. In the present study, pulsed laser deposition (PLD) was used to deposit $\mathrm{ZrO}_{2}$ and silver (Ag)$\mathrm{ZrO}_{2}$ composite coatings onto $316 \mathrm{~L}$ stainless steel $(316 \mathrm{~L}$ SS). Phase purity, surface roughness and surface morphology, thickness of the coatings and elemental compositions of the coatings were analyzed using X-ray diffraction (XRD), atomic force microscopy (AFM) and scanning electron microscopy (SEM) with energy dispersive X-ray spectroscopy (EDS). Total viable count (TVC) and epifluorescence microscopy analysis were studied to evaluate antimicrobial efficiency of $\mathrm{ZrO}_{2}$ and $\mathrm{Ag}-\mathrm{ZrO}_{2}$ composite coatings using gram negative (gram -ve) Escherichia coli (E.coli) and gram positive (gram +ve) Staphylococcus aureus (S.aureus). On the basis of the present study, it could be speculated that $\mathrm{ZrO}_{2}$ coatings exhibited antibacterial activity against only E.coli, whereas $\mathrm{Ag}-\mathrm{ZrO}_{2}$ composite coatings showed superior activity against E.coli and S.aureus strains.
\end{abstract}

Keywords Zirconia $\cdot$ Silver - Biomedical implants · Thin films $\cdot$ PLD $\cdot$ Antibacterial effect

G. Pradhaban · G. S. Kaliaraj ( $₫) \cdot$ V. Vishwakarma Centre for Nanoscience and Nanotechnology, Sathyabama University, Chennai 600119, India

e-mail: gsnanotech@gmail.com

\section{Introduction}

In recent years, the number of implant devices have increased for various implant surgeries takes leading effort across the world (Nathan et al. 2012). The demands of implants have significantly increased not only for new patients but also for patients who must receive revision surgeries. After implantation, the implant materials should not cause allergic and hypersensitive reactions. Hence, biocompatibility is an essential requirement for an artificial implant to exhibit chemical bonding to living tissues upon the formation of bone-like apatite layer on its surface in any simulated body environment (Kokubo 2008; Arisara et al. 2012). In order to improve bioactivity, biocompatibility and implant longevity, thin films which are having nano crystalline achieved considerable breakthrough in the field of biomedical sciences due to their exceptional physical and chemical properties (Holleck 1991). Nanostructured metal oxide thin films and metal complexes have emerged as class materials which are increasingly being studied for health-related applications. Highly ionic metal oxides are interesting in physical, chemical and antibacterial properties (Gu et al. 2007; Jangra et al. 2012).

Among various metal oxides, $\mathrm{ZrO}_{2}$ is used extensively for various implant devices because of its good mechanical and biocompatibility properties and used for esthetic devices too. As a ceramic, $\mathrm{ZrO}_{2}$ exhibits several advantages such as corrosion resistance, mechanical strength and fracture toughness. The enhanced properties of $\mathrm{ZrO}_{2}$ attributed to high crystallinity and nano crystalline $\mathrm{ZrO}_{2}$ express better biocompatibility and bioactivity nature (Uchida et al. 2002). The requirement of $\mathrm{ZrO}_{2}$ implants have been increased significantly from $4,28,000$ to 2.16 
million per year for total knee arthroplasty. Hip replacement is also one of the important applications of $\mathrm{ZrO}_{2}$ among the various implants. Chevalior stated that more than $6,00,000 \mathrm{ZrO}_{2}$ femoral have been implanted worldwide (Chevalier 2006). The ceramic $\mathrm{ZrO}_{2}$ implant materials, with ISO standard No. 13356, are extensively being used. Even though $\mathrm{ZrO}_{2}$ thin films are near ideal biomaterial, their use does not always guarantee adequate results. In this aspect, Microbial invasion and colonization on $\mathrm{ZrO}_{2}$ implant materials is still a major challenge against implant durability. Since $\mathrm{ZrO}_{2}$ thin film exhibits antibacterial activity against only E.coli, it is not active against a wide variety of microbial species and thereby implanted material is prone to bacterial attack that may eventually lead to inflammation and destructive of the implants (Jangra et al. 2012). Among the various bacterial species Enterococcus faecalis, E.Coli, Cornybacterium sp., and Staphylococcus sp., predominantly invade the implant materials and cause orthopedic infections (Udo 2009). Hence, microbial invasion is an important crisis for implant success and durability. Diagnosis and treatment for implant failure is the tedious process in case of load bearing and hip, knee artroplasty implants. Recently, addition of antimicrobial metallic materials into metal oxide implants is suitable choice to elevate the antimicrobial property, especially from implant-associated infectious bacteria (Jelinek et al. 2013). In that perspective, Silver has been used in many medical devices such as bone cements, catheters, orthopedic fixation pins, dental implants, and cardiac prostheses (Lansdown 2006). One of the best known uses of silver in medicine is to serve as the primary antimicrobial agent in topical creams to heal severe burns (Lansdown 2007; Atiyeh et al. 2007). Since bacterial infections are associated with prosthetic failures, silver has been considered as a medical coating for broad range of microbial inactivation. Since hydroxyapatite has poor mechanical property, $\mathrm{Ag}-\mathrm{ZrO}_{2}$ thin composite coatings are studied extensively to enhance biocompatibility, mechanical, and antimicrobial behavior. $\mathrm{Ag}-\mathrm{ZrO}_{2}$ thin composite coatings have been fabricated using several methods such as sol-gel, physical vapor deposition, and plasma spraying (Ewald et al. 2006; Zheng et al. 2009; Chen et al. 2007). Among the various deposition techniques, pulsed laser deposition (PLD) is one of the novel methods to modify the metal surface. It gives high deposition rate, good stoichiometry, and better adhesion. In this work, $\mathrm{ZrO}_{2}$ and $\mathrm{Ag}-\mathrm{ZrO}_{2}$ composite coatings were prepared by PLD. The structural and surface topography of the coatings were studied by XRD and AFM, respectively. Coating's thickness and morphology were analyzed by SEM. Elemental composition and mapping were analyzed by EDS. The efficiency of antibacterial properties of $\mathrm{ZrO}_{2}$ and $\mathrm{Ag}-\mathrm{ZrO}_{2}$ composite coatings were evaluated and compared against E.coli and S.aureus bacteria.

\section{Methods}

\section{Substrate pretreatment}

Medical grade stainless steel 316L (316L SS) and silicon substrate (for characterization) were selected as a substrate and pretreatment was performed. Briefly, substrates were cut into $1 \times 1 \mathrm{~cm}^{2}$ using automated cutting machine (Struers, Tegramin-25, Denmark). Mirror polishing was done using automated polishing machine (Struers A/S, DK2750 Ballerup, Denmark) and silicon carbide emery papers (240-1000 mesh sizes) were used to reduce the surface roughness of the substrates. Finally, mirror polished substrates were treated with trichloroethylene in order to remove the rust and ultrasonicated for $15 \mathrm{~min}$ before coatings.

Deposition of silver- $\mathrm{ZrO}_{2}$ composite coatings and their characterizations

The commercial $\mathrm{ZrO}_{2}$ powders with $99.99 \%$ purity were pressed with $40 \mathrm{MPa}$ in the $8 \mathrm{~mm}$ mold to prepare disc. This disc was subjected to heat treatment at $900{ }^{\circ} \mathrm{C}$ for $5 \mathrm{~h}$ in air atmosphere with heating rate of $10^{\circ} \mathrm{C} / \mathrm{min}$. The resultant $8 \mathrm{~mm}$ diameter and $3 \mathrm{~mm}$ thickness $\mathrm{ZrO}_{2}$ disc and commercial silver with $25 \mathrm{~mm}$ diameter and $2 \mathrm{~mm}$ thickness disc were used as targets in this experiment. The vacuum chamber was evacuated by air cooled turbomolecular pump and kept at $1 \times 10^{-6} \mathrm{~m}$ bar as a base pressure as well as deposition pressure. A Q-switched NdYAG laser operating at wavelength $355 \mathrm{~nm}$ with fluence of $2 \mathrm{~J} / \mathrm{cm}^{2}$ and repetition rate of $10 \mathrm{~Hz}$ is allowed into the chamber through a quartz window. The laser beam with $2 \mathrm{~mm}$ diameter is focused on the targets at the angle of $45^{\circ}$. For $\mathrm{Ag}-\mathrm{ZrO}_{2}$ composites coatings, same $8 \mathrm{~mm}$ diameter $\mathrm{ZrO}_{2}$ target is fixed on $25 \mathrm{~mm} \mathrm{Ag}$ target (Fig. 1). Target and substrate distances were kept at $45 \mathrm{~mm}$. Prior to deposition, both targets were ablated with 3,000 pulses to remove the surface contamination to get high-purity coatings with shutter between targets and substrates and 45,000 pulses have been applied on target for each coating. The substrates were kept at a constant temperature of $200{ }^{\circ} \mathrm{C}$ with ramping rate of $10{ }^{\circ} \mathrm{C} / \mathrm{min}$ for both the deposition. Both depositions are performed at similar conditions.

The phase structure of $\mathrm{ZrO}_{2}$ and $\mathrm{Ag}-\mathrm{ZrO}_{2}$ composite coatings were analyzed by glancing angle $\mathrm{X}$-ray diffractometer (Rigaku, smart lab $9 \mathrm{KW}$, japan) using a $\mathrm{CuK} \alpha=1.5406 \AA$ radiation source. The surface of the 


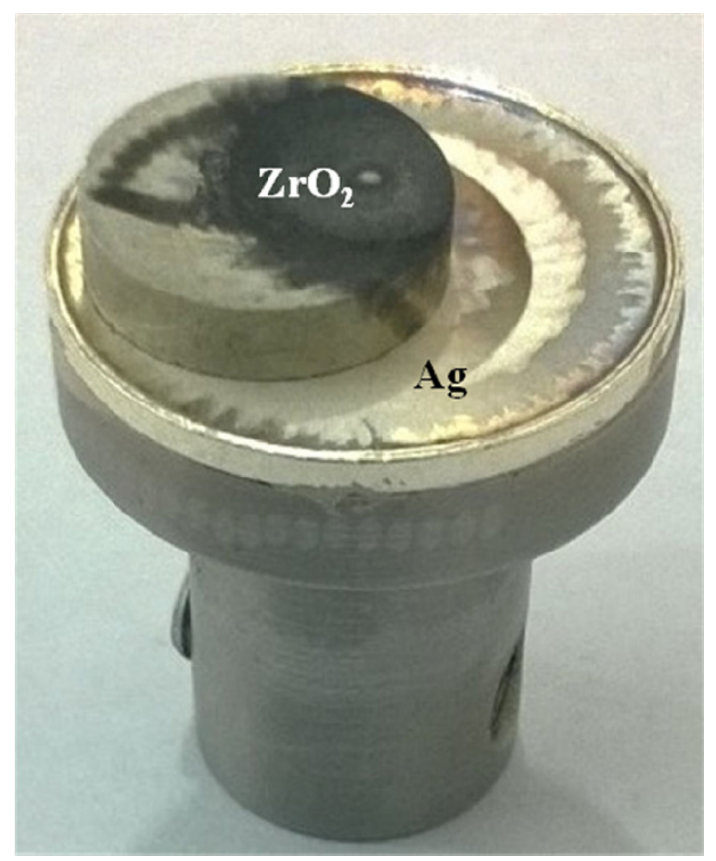

Fig. 1 Target holder consists of $\mathrm{Ag}$ and $\mathrm{ZrO}_{2}$

coating was characterized by molecular imaging atomic force microscopy (AFM) using SLOVER PRO, multi mode scanning probe microscope manufactured by M/s NTMDT, the Irelands.

\section{Bacterial adhesion study}

Bacterial strains

E.coli (MTCC 443) and S.aureus (MTCC 3160) bacterial strains were used for this study. Cultures were maintained on nutrient broth at $37^{\circ} \mathrm{C}$.

Preparation and inoculation of organisms

The bacterial suspensions were prepared by taking a single colony from the stock bacterial culture with a loop and inoculating $20 \mathrm{ml}$ of sterile nutrient broth in a 100-ml Erlenmeyer flask. The flask was then incubated in a shaking incubator at $37^{\circ} \mathrm{C}$ at $110 \mathrm{rpm}$ for $12 \pm 2 \mathrm{~h}$. After incubation, $0.4 \mathrm{ml}$ of the overnight inoculum was transferred to a 100-ml Erlenmeyer flask containing $20 \mathrm{ml}$ nutrient broth and incubated in a shaking incubator for $3 \mathrm{~h}$ at $37{ }^{\circ} \mathrm{C}$ and $110 \mathrm{rpm}$. The number of bacteria in the $3 \mathrm{~h}$ culture was estimated by measuring the optical density of the culture at $660 \mathrm{~nm}$ (Corning colorimeter 253). An optical density of between 0.1 and 0.3 was roughly equal to a concentration $2.5 \times 10^{8} \mathrm{CFU} / \mathrm{ml}$.
Sterilizations of test samples

$\mathrm{ZrO}_{2}$ and $\mathrm{Ag}-\mathrm{ZrO}_{2}$ composite onto $316 \mathrm{~L}$ SS were sterilized under UV lamp with $5 \mathrm{~cm}$ distance for $10 \mathrm{~min}$ to obtain surface sterilization. Post exposure, specimens were transferred to sterilized disposable petriplates to avoid cross contamination. All the specimens were retained in the petriplates during each experiment.

\section{Antibacterial analysis}

The cultured bacterial strains were inoculated in $10 \mathrm{ml}$ phosfate-buffered saline ( $\mathrm{PBS}$; g/l: $\mathrm{KCl} 0.2, \mathrm{KH}_{2} \mathrm{PO}_{4} 0.2$, $\mathrm{NaCl} 8.0, \mathrm{Na}_{2} \mathrm{HPO}_{4 \cdot 12} \mathrm{H}_{2} \mathrm{O}$ ) solution to reach approximate target concentration of $1 \times 10^{5}$ colony forming units/milliliter $(\mathrm{CFU} / \mathrm{ml})$. The saline solution containing bacteria was used for the 'drop-method' antibacterial experiments (Sun et al. 2008). The samples were placed in the sterilized petridishes. Then $100 \mu \mathrm{l}$ of saline solution containing bacteria was added dropwise onto the surface of each deposited film. The samples were laid at ambient temperature for $12 \mathrm{~h}$ to evaluate absolute initial antimicrobial properties of test specimens. Incubated samples were washed with $5 \mathrm{ml}$ of PBS in the sterilized petridish. Then $10 \mu \mathrm{l}$ each of bacteria suspension was dispersed on the culture medium and incubated for $24 \mathrm{~h}$ at $37{ }^{\circ} \mathrm{C}$. After that, Total viable count (TVC) was enumerated to evaluate viable bacterial cells arising from solid medium. The number of bacteria-forming units (CFU) was counted, and the reduction of bacteria, $R$, was calculated from

$R=\frac{(B-A)}{B} 100(\%)$,

where $A$ is the CFU recovered from the uncoated 316L SS (data is not shown) and $B$ is the CFU recovered from the coated samples over the desired contact period ( $24 \mathrm{~h})$.

For live/dead cell analysis, same quantity of bacterial suspension was poured onto test specimens for $30 \mathrm{~min}$. The incubated samples were gently washed in PBS to remove the unbound bacterial cells. Finally, acridine orange (AO) was added onto specimens and observed using Nikon Eclipse E600 Epifluorescence microscope (excitation filter BP 490; barrier filter O515).

\section{Results and discussion}

Figure 2 shows X-ray diffraction patterns of $\mathrm{ZrO}_{2}$ and $\mathrm{Ag}-$ $\mathrm{ZrO}_{2}$ composite coatings deposited at $200{ }^{\circ} \mathrm{C}$ onto $316 \mathrm{~L} \mathrm{SS}$ substrate with parallel-beam (PB) diffraction geometry. $\mathrm{ZrO}_{2}$ coating shows the diffraction at (002), (102), (112), (221), (202) and (302) with corresponding 28.15, 33.92, 


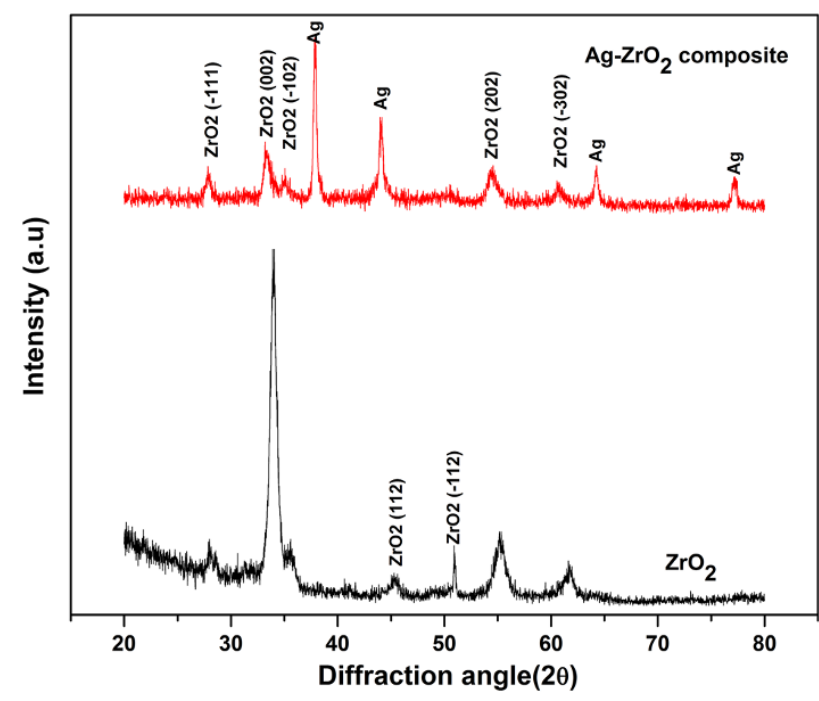

Fig. 2 XRD pattern of $\mathrm{ZrO}_{2}$ and $\mathrm{Ag}-\mathrm{ZrO}_{2}$ composite coatings

$35.56,45.32,50.87,55.19$ and $61.66^{\circ} 2 \theta$ positions. $\mathrm{Ag}-$ $\mathrm{ZrO}_{2}$ composite coatings can also be identified with (111), (002), (-102), (112), (-221), (202) and (302) planes with corresponding $2 \theta$ position of $27.95,33.30,35.15,37.93$, $44.09,54.47,60.74,64.24$ and $77.19^{\circ}$. For the estimation of average crystalline size, the following Scherrer equation is employed (Suryanarayan and Norton 1998).

$t=0.9 \lambda / \beta \cos \theta$

where $\lambda=$ wavelength of $\mathrm{X}$-ray source, $\beta=$ full width half maximum (FWHM) corresponding to XRD peaks.

The crystalline size of $\mathrm{ZrO}_{2}$ is calculated from its peak broadening and crystalline size found to be $16.19 \mathrm{~nm}$. In case of $\mathrm{Ag}-\mathrm{ZrO} 2$ composite coatings, crystalline size of $\mathrm{ZrO}_{2}$ found to be $13.56 \mathrm{~nm}$. The crystalline of $\mathrm{Ag}$ was calculated as $27.14 \mathrm{~nm}$ and no secondary phase of $\mathrm{Ag}$ was observed. It clearly indicates that crystallinity of $\mathrm{Ag}$ fully improved and crystalline size was larger than that of $\mathrm{ZrO}_{2}$. At this low substrate temperature $\left(200{ }^{\circ} \mathrm{C}\right)$, some grains of the $\mathrm{ZrO}_{2}$ material grows amorphous nature, whereas $\mathrm{Ag}$ grain growth fairly formed crystalline nature and this formation inhibited further grain growth of $\mathrm{ZrO}_{2}$ in $\mathrm{Ag}-\mathrm{ZrO}_{2}$ composite coatings.

Typical nano topography using two-dimensional (2D) and three-dimensional (3D) images of AFM with surface profiles of $\mathrm{ZrO}_{2}$ and silver- $\mathrm{ZrO}_{2}$ composite coatings are shown in Figs. 3, 4. A comparative AFM analysis indicated that the slightly heterogeneous surface with increased grains exhibited in $\mathrm{ZrO}_{2}$ coating; for $\mathrm{Ag}-\mathrm{ZrO}_{2}$ composite coatings, homogenous surfaces with fine topographical alterations are observed. The degree of roughness and grains in $\mathrm{ZrO}_{2}$ coating $\left(R_{\mathrm{a}}=1.4541 \mathrm{~nm}\right)$ is slightly increased than silver- $\mathrm{ZrO}_{2}\left(R_{\mathrm{a}}=1.04816 \mathrm{~nm}\right)$ coatings. $\mathrm{ZrO}_{2}$ coatings showed the maximum and minimum grain sizes in the range of 4-10 $\mathrm{nm}$ along with few agglomerations. For $\mathrm{Ag}-\mathrm{ZrO}_{2}$ composite, it has shown as $3-8 \mathrm{~nm}$. From 2D and 3D profile of AFM surface profile analysis concludes that the addition of silver content in $\mathrm{ZrO}_{2}$ results in a minute decrease of both the grain size and surface roughness due the nucleation matter (Subramanian and Jayachandran 2007).

Morphology as well as cross section of the $\mathrm{ZrO}_{2}$ and $\mathrm{Ag}-\mathrm{ZrO}_{2}$ composite coatings is shown in Fig. 5. Both $\mathrm{ZrO}_{2}$ (Fig. 5a) and $\mathrm{Ag}-\mathrm{ZrO}_{2}$ (Fig. 5b) composite coatings showed dense, smooth and defect-free surface along with smaller grain size. Few droplets or agglomeration of grains was also observed in both coatings. Formation of droplets is one of the intrinsic properties of laser ablation technique (Willmott and Huber 2000). The total thickness of the $\mathrm{ZrO}_{2}$ and $\mathrm{Ag}-\mathrm{ZrO}_{2}$ composite coatings is evaluated from the cross-sectional view of the samples and found to be 120 and $154 \mathrm{~nm}$, respectively. The slight variation of thickness attributed to the difference in ablation rate of $\mathrm{Ag}$ and $\mathrm{ZrO}_{2}$. Generally, pure metals have more ablation rates than ceramic materials in PLD technique. In this case the ablation rate of metallic $\mathrm{Ag}$ is comparatively more than that of $\mathrm{ZrO}_{2}$ ceramic material.

Figure 6 shows the compositional analysis of $\mathrm{ZrO}_{2}$ coatings contains both zirconium $(\mathrm{Zr})$, oxygen $(\mathrm{O})$ and silicon ( $\mathrm{Si}$ ). Figure 7 shows the compositional analysis and elemental mapping of $\mathrm{Ag}-\mathrm{ZrO}_{2}$ composite coatings, in which, the wt $\%$ of Ag was 1.17. Si peak was also observed due to the surface effect. From the compositional analysis, the presence of $\mathrm{Zr}, \mathrm{O}$ and $\mathrm{Ag}, \mathrm{Zr}$, O were confirmed in $\mathrm{ZrO}_{2}$ and $\mathrm{Ag}-\mathrm{ZrO}_{2}$ composite coatings.

Antimicrobial activity of $\mathrm{ZrO}_{2}$ and $\mathrm{Ag}-\mathrm{ZrO}_{2}$ composite coatings coated $316 \mathrm{~L}$ SS was evaluated by determining TVC. $\mathrm{ZrO}_{2}$ coating shows antibacterial activity of about $99 \%$ (data are not shown) against E.coli and exhibits very less antibacterial efficiency about $46 \%$ against S.aureus. On the other hand, drastic growth arrest is observed on $\mathrm{Ag}-\mathrm{ZrO}_{2}$ composite coatings with the antimicrobial efficiency of 99.5 and $99 \%$ for E.coli and S.aureus, respectively. During incubation, when aqueous bacterial solutions are exposed onto coating surfaces, many of the bacteria have a possibility to attach directly to the surface. Since silver is present on the surface of the samples, metallic silver ions leached from coating surface and affect both adhered and non adhered bacterial cell wall (Sondi and Sondi 2004). The mechanism of both bacterial strains against $\mathrm{Ag}-\mathrm{ZrO}_{2}$ composite coatings varies as (a) $\mathrm{Ag}$ ions may bind with bacterial cell surface proteins such as porins, $\mathrm{OmpF}$ and $\mathrm{OmpC}$ and produce imbalanced membrane diffusion in gram-negative bacteria; (b) metallic $\mathrm{Ag}$ ions bind with surface anionic proteins and lost their membrane rigidity and increase the cell wall porosity. Hence, the above mechanisms elevate oxidative stress; 
(a)
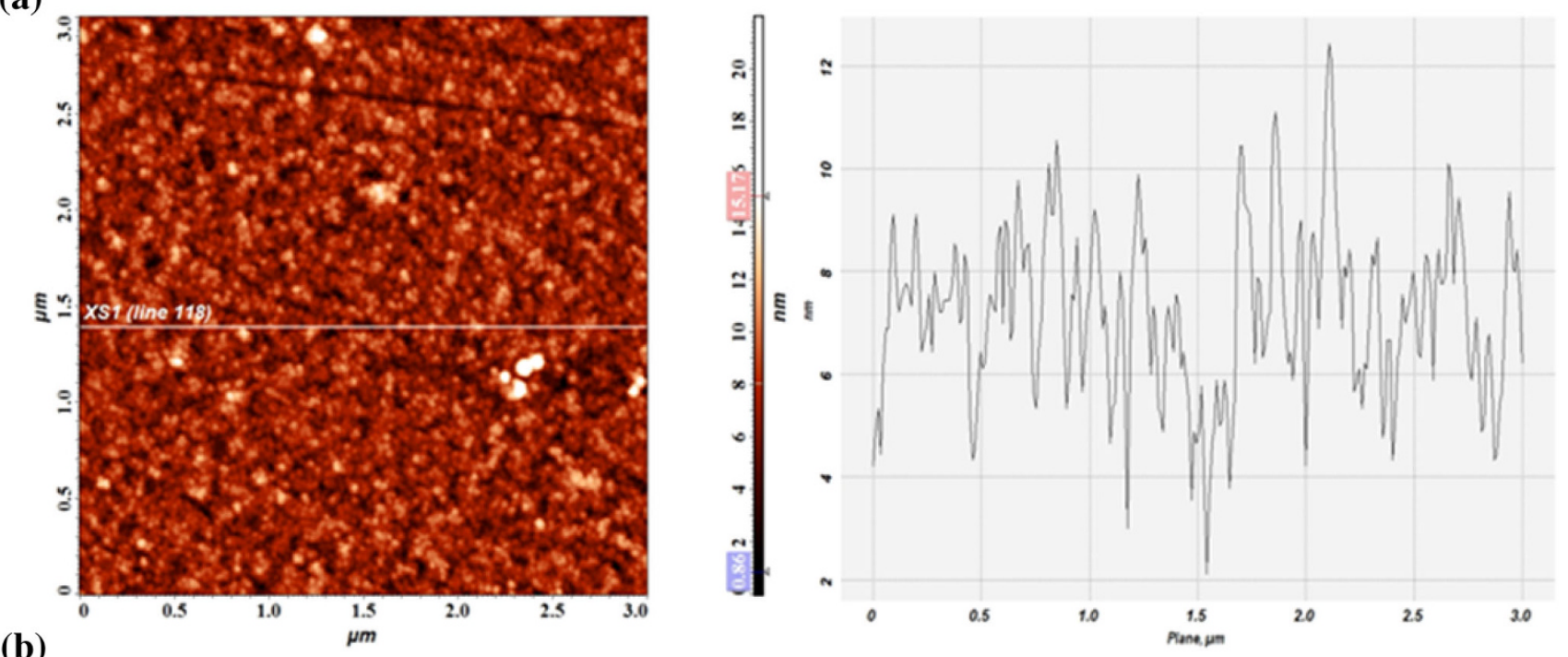

(b)
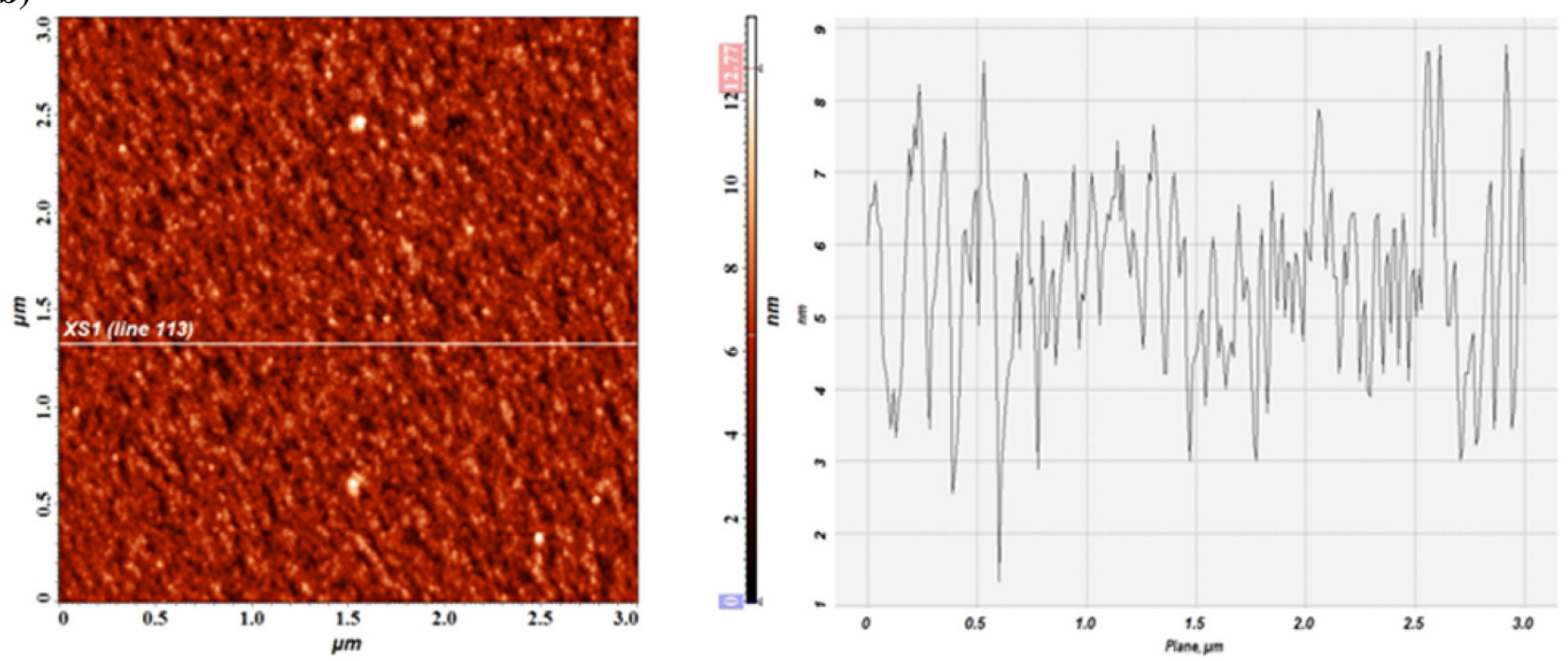

Fig. 3 Two-dimensional (2D) AFM images and surface profiles of $\mathrm{ZrO}_{2}$ (a) and $\mathrm{Ag}-\mathrm{ZrO}$ composite coatings (b) coated 316L SS from approximately $3 \times 3 \mu \mathrm{m}$ scanned areas
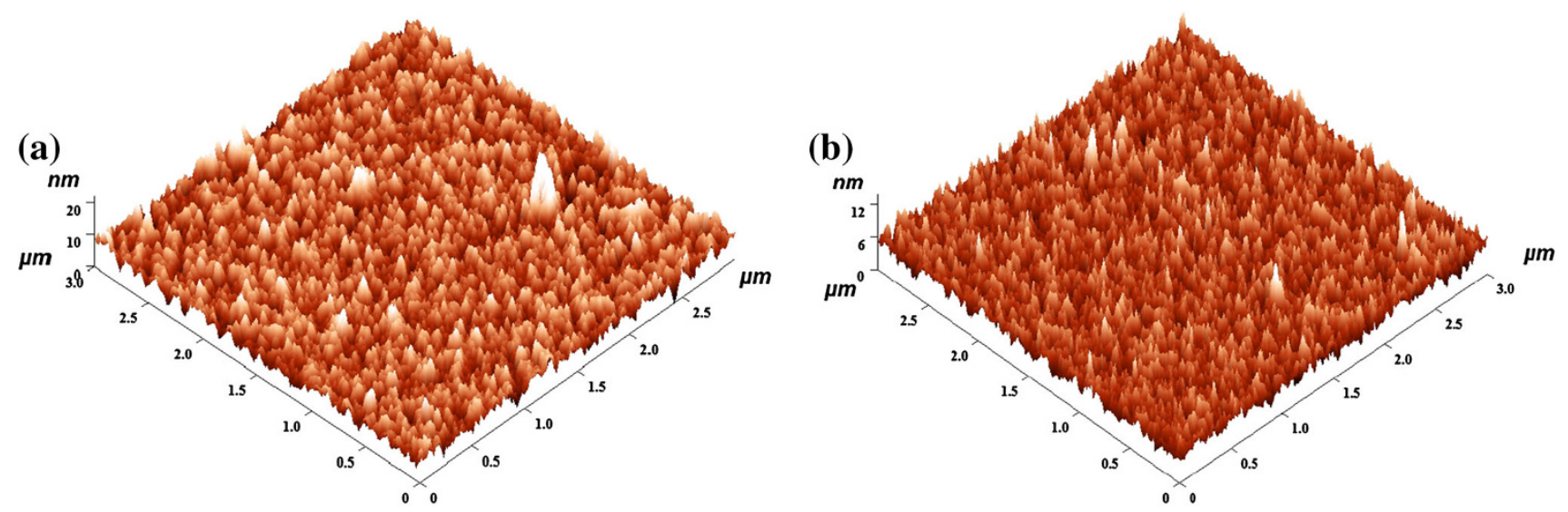

Fig. 4 Three-dimensional (3D) projections of typical AFM images and surface profiles of $\mathrm{ZrO}_{2}$ (a) and $\mathrm{Ag}-\mathrm{ZrO}{ }_{2}$ composite coatings (b) coated $316 \mathrm{~L}$ SS from approximately $3 \times 3 \mu \mathrm{m}$ scanned areas 

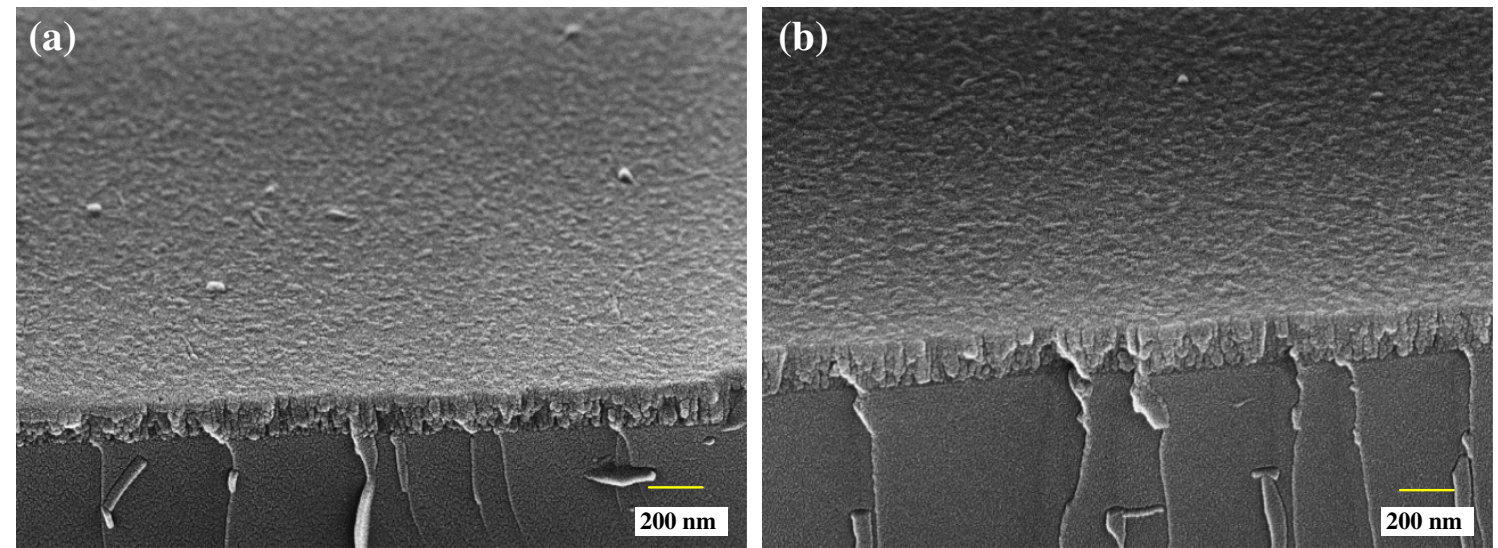

Fig. 5 Cross-sectional images of $\mathrm{ZrO}_{2}$ and $\mathrm{Ag}-\mathrm{ZrO}_{2}$ composite coatings

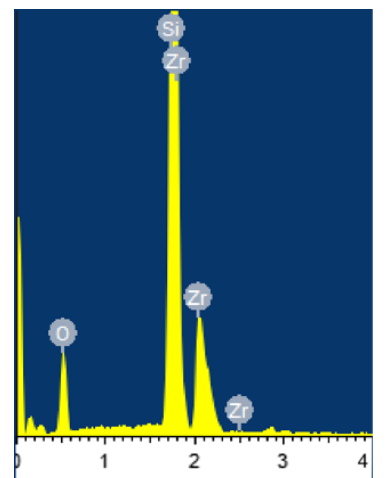

\begin{tabular}{|c|c|}
\hline Element & Weight\% \\
\hline O K & 31.55 \\
\hline Si K & 41.89 \\
\hline Zr L & 26.56 \\
\hline Totals & 100.00 \\
\hline
\end{tabular}

Fig. 6 Compositional analysis of $\mathrm{ZrO}_{2}$ coating

thereby free radicals production occurs which arises reactive oxygen species, resulting structural changes and cell damage occur. In addition to that, the metallic silver ions are effectively involved in binding with sulfur or phosphorus-containing soft bases, such as R-S-R, R-SH, $\mathrm{RS}^{-}$or $\mathrm{PR}_{3}$ which is present in cell membrane and phosphate group of DNA which is located inside the cell (Bragg and Rainnie 1974; McDonnell and Russell 1999; Darouiche 1999). As a result, the bacterial growth is effectively inhibited within a short time of exposure. From the TVC results, it could be speculated that $\mathrm{ZrO}_{2}$ coating worked out exhibited better antibacterial activity only against E.coli and no activity for S.aureus. It is due to the heterogeneity structure and chemical composition of the outer membrane of gram +ve and gram - ve bacteria (Thomas et al. 2010). The calculated TVC of gram (-)ve and gram $(+)$ ve test organisms are to be $1.78 \times 10^{2}$, $1.02 \times 10^{4}$ for $\mathrm{ZrO}_{2}$ coating and 92, 164 for $\mathrm{Ag}-\mathrm{ZrO}_{2}$ composite coatings, respectively.

Figure 8 depicts epifluorescence microscopy images of $\mathrm{ZrO}_{2}$ and $\mathrm{Ag}-\mathrm{ZrO}_{2}$ composite coated 316L SS. In principle, live cells exhibited orange fluorescence and dead cells
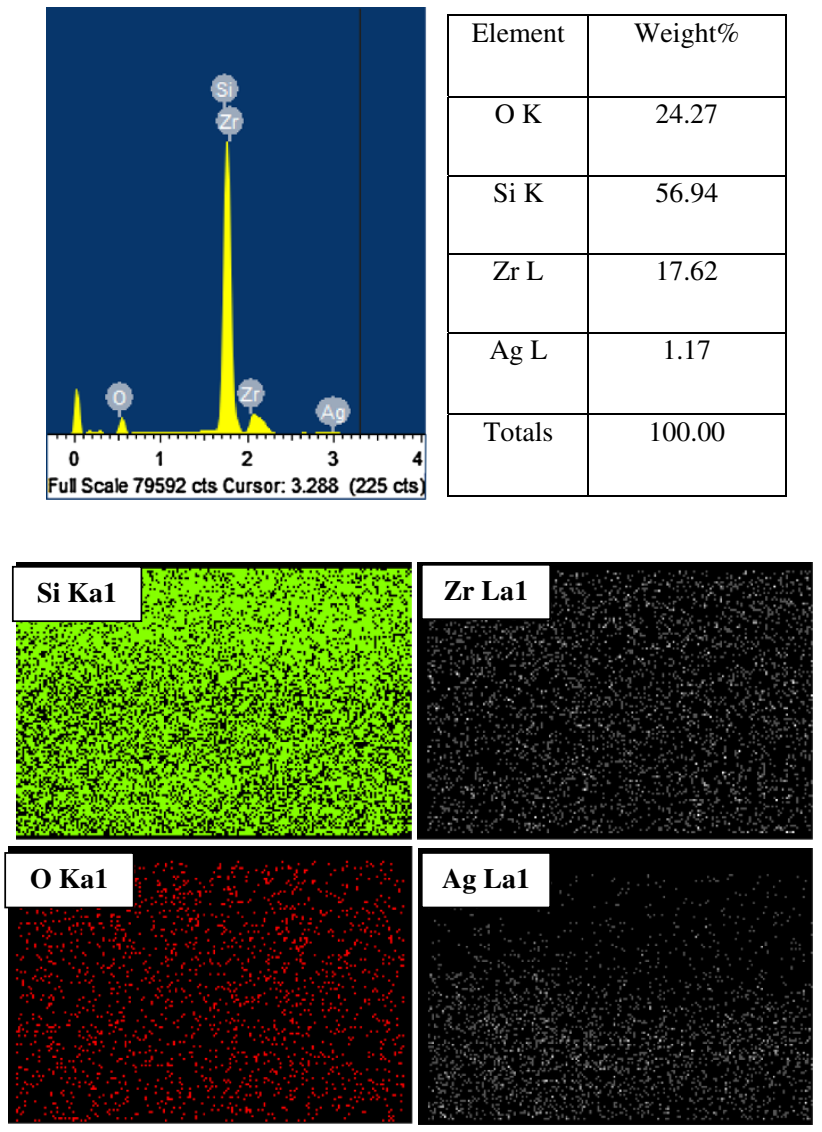

Fig. 7 Elemental and compositional analysis of $\mathrm{Ag}-\mathrm{ZrO}_{2}$ composite coating

exhibited green color due to the interaction of $\mathrm{AO}$ with cellular RNA (Vinita Vishwakarma et al. 2009). Epifluorescence results exhibited similar results with TVC analysis. Bacterial inoculated $\mathrm{ZrO}_{2}$ coating shows green fluorescence for E.coli bacteria; orange color fluorescence for S.aureus. Result concludes that $\mathrm{ZrO}_{2}$ coating shows bacterial activity against E.coli and fails to express the 

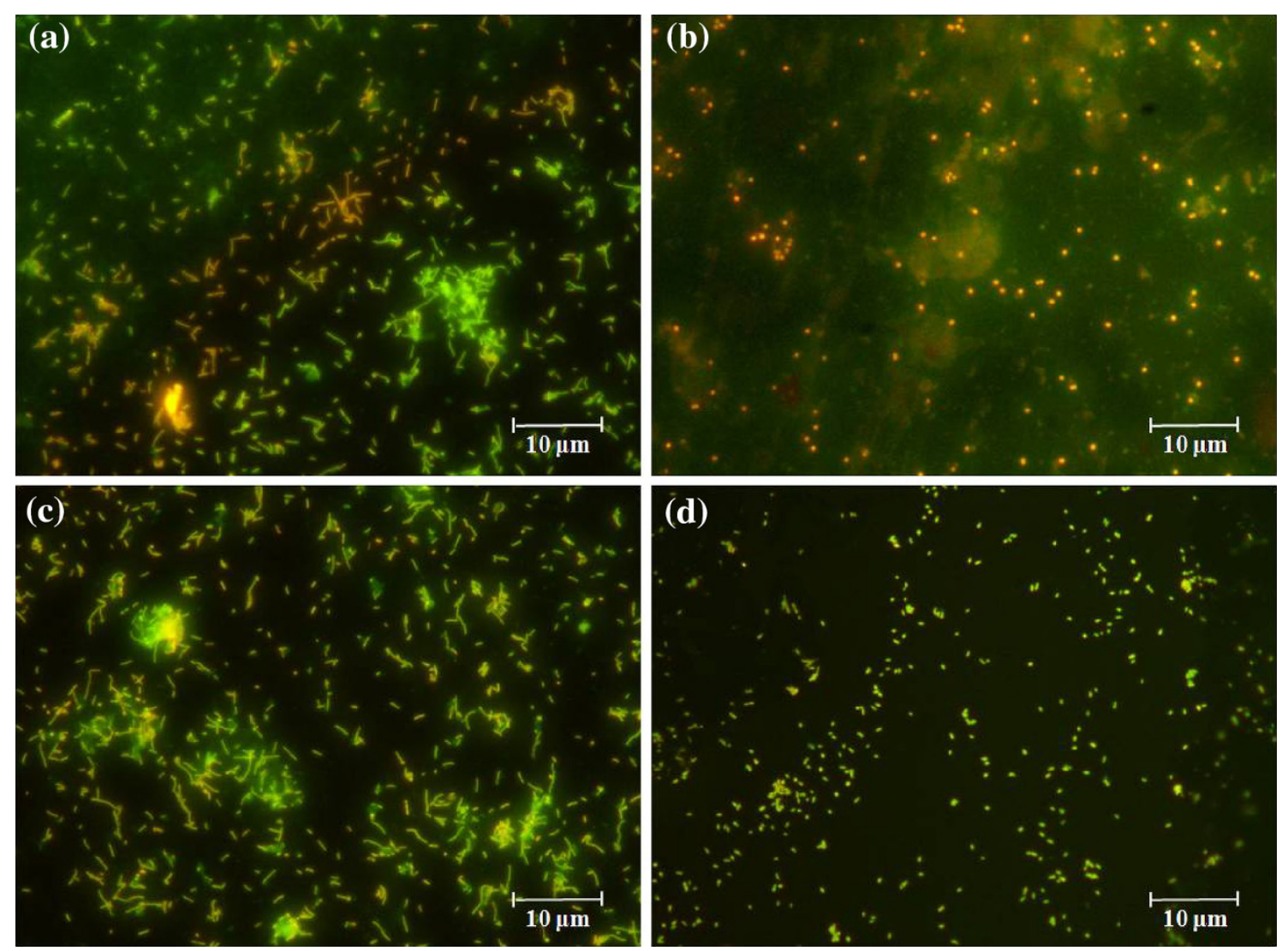

Fig. 8 Epifluorescence microscopy images of $\mathrm{ZrO}_{2}$ (Fig. 5a E.Coli and b S.aureus) and $\mathrm{Ag}-\mathrm{ZrO}_{2}$ composite coatings (Fig. 5c E.Coli and d S.aureus)

bactericidal nature against S.aureus. In case of $\mathrm{Ag}-\mathrm{ZrO}_{2}$ composite coatings, both E.coli and S.aureus show green fluorescence indicates dead cells. The exposed bacteria are interacting with $\mathrm{Ag}$ ions which undergo severe changes in and around the bacterial cell wall thereby elevating deterioration of bacterial cell wall. Besides, strong interaction of silver ions with intracellular components affects further cellular RNA synthesis which leads bacterial death.

\section{Conclusions}

$\mathrm{ZrO}_{2}$ and $\mathrm{Ag}-\mathrm{ZrO}_{2}$ composite coatings were successfully prepared using PLD technique. XRD examination reveals that monoclinic phase for $\mathrm{ZrO}_{2}$ and mixed phase for Ag$\mathrm{ZrO}_{2}$ composite coatings were obtained. AFM morphology of the coatings clearly indicated that the grains are evenly distributed. Elemental analysis by EDS confirmed the presence of $\mathrm{Ag}$ in $\mathrm{Ag}-\mathrm{ZrO}_{2}$ composite coatings about 1.17 wt $\%$ of Ag. The antimicrobial efficiency was performed using TVC and epifluorescence microscopy analysis in which $\mathrm{Ag}-\mathrm{ZrO}_{2}$ composite coatings shows superior antibacterial when compare to $\mathrm{ZrO}_{2}$ coating. Hence, the 1.17 wt $\% \mathrm{Ag}$ content exhibits superior antibacterial activity and it may be the good candidate for biomedical applications.

Acknowledgments The authors would like to thank Dr. Jeppiaar, Chancellor, Sathyabama University, Chennai for financial assistance.

Open Access This article is distributed under the terms of the Creative Commons Attribution License which permits any use, distribution, and reproduction in any medium, provided the original author(s) and the source are credited.

\section{References}

Arisara T, Virote B, Nirun W (2012) Apatite deposition on $\mathrm{ZrO}_{2}$ thin films by DC unbalanced magnetron sputtering. Advan Mater Physic Chem 2:45-48

Atiyeh BS, Costagliola M, Hayek SN, Dibo SA (2007) Effect of silver on burn wound infection control and healing: review of the literature. Burns 33:139-148

Bragg PD, Rainnie DJ (1974) The effect of silver ions on the respiratory chains of Escherichia coli. Can J Microbiol 20:83-889

Chen W, Oh S, Ong AP, Oh N, Liu Y, Courtney HS, Appleford M, Ong JL (2007) Antibacterial and osteogenic properties of silvercontaining hydroxyapatite coatings produced using a sol gel process. J Biomed Mater Res A 82A:899-906

Chevalier J (2006) What future for zirconia as a biomaterial? Biomat 27:535-543 
Darouiche RO (1999) Anti-infective efficacy of silver-coated medical prostheses. Clin Infect Dis 29:1371-1377

Ewald A, Gluckermann SK, Thull R, Gbureck U (2006) Antimicrobial titanium/silver PVD coatings on titanium. Biomed Eng Online 5:1-10

Gu FX, Karnik R, Wang AZ, Alexis F, Nissenbaum EL, Hong S, Langer RS, Farokhzad OC (2007) Targeted nanoparticles for cancer therapy. Nanotoday 2:14-21

Holleck H (1991) Designing advanced coatings for wear protection. Surf Eng 7(2):137-144

Jangra SL, Stalin K, Dilbaghi N, Kumar S, Tawale J, Singh SP, Pasricha R (2012) Antimicrobial activity of zirconia $\left(\mathrm{ZrO}_{2}\right)$ nanoparticles and zirconium complexes. J Nanosci Nanotech 12(7105-7): 112

Jelinek M, Kocourek T, Remsa J, Weiserova M, Jurek K, Miksovsky J, Strnad J, Galandakova A, Ulrichova J (2013) Antibacterial, cytotoxicity and physical properties of laser-Silver doped hydroxyapatite layers. Mater Sci Eng C 33:1242-1246

Kokubo T (2008) Bioceramics and their clinical applications. Woodhead, England

Lansdown ABG (2006) Silver in health care: antimicrobial effects and safety in use. Curr Probl Dermatol 33:17-34

Lansdown AB (2007) Critical observations on the neurotoxicity of silver. Crit Rev Toxicol 37:237-250 Lansdown 2007

McDonnell G, Russell AD (1999) Antiseptics and disinfectants: activity, action, and resistance. Clin Microbiol Rev 12:147-179

Nathan AT, Rachael AO, Hongyan Ma, James DB, John DW, Ketul CP (2012) Antibacterial effects of silver-doped hydroxyapatite thin films sputter deposited on titanium. Mater Sci Eng C $32: 2135-2144$
Sondi Sondi BS (2004) Silver nanoparticles as antimicrobial agent: a case study on E. coli as a model for Gram-negative bacteria. J Colloid Interface Sci 275:177-182

Subramanian B, Jayachandran M (2007) Characterization of reactive magnetron sputtered nanocrystalline titanium nitride (TiN) thin films with brush plated $\mathrm{Ni}$ interlayer. J Appl Electrochem 37:1069-1075

Sun SQ, Sun B, Zhang W, Wang D (2008) Preparation and antibacterial activity of $\mathrm{Ag}-\mathrm{Tio} 2$ composite film by liquid phase deposition (LPD) method. Bull Mater Sci 31:61-66

Suryanarayan RC, Norton MG (1998) X-ray diffraction: a practical approach. Plenum Press, New York

Thomas JS, Daniel K, Suzanne W (2010) The bacterial cell envelope. Cold Spring Harb Perspect Biol 2:1-16

Uchida M, Kim HM, Kokubo T, Tanaka K, Nakamura T (2002) Structural dependence of apatite formation on zirconia gels in a simulated body fluid. J Ceram Soc Japan 110:710-715

Udo G (2009) Pathogenic organisms in hip joint infections. Int J Med Sci 6:234-240

Vishwakarma Vinita, Josephine J, George RP, Krishnan R, Dash S, Kamruddin M, Kalavathi S, Manoharan N, Tyagi AK, Dayal RK (2009) Antibacterial copper-nickel bilayers and multilayer coatings by pulsed laser deposition on titanium. Biofoul 25:705-710

Willmott PR, Huber JR (2000) Pulsed laser vaporization and deposition. Rev Modern Physic 72:315-328

Zheng X, Chen Y, Xie Y, Ji H, Huang L, Ding C (2009) Antibacterial property and biocompatibility of plasma sprayed hydroxyapatite/ silver composite coatings. J Therm Spray Technol 18:463 